\title{
A Brief Review on Plastic Pollution and Roads Towards its Reduction
}

\author{
Vandita Srivastava ${ }^{*}$ \\ ${ }^{1}$ Kanahiya Lal D.A. V. (P.G.) College, Roorkee- 247667, Uttarakhand (India) \\ *Corresponding Author Email: vandita61@gmail.com
}

Received: 30.8.2021; Revised: 12.9.2021; Accepted: 29.9.2021

(C)Society for Himalayan Action Research and Development

\begin{abstract}
:
Plastic, owing to its excellent strength to weight ratio, durability, low cost, low maintenance and corrosion free characteristics, has found a wide range of applications, in packaging, shopping/garbage bags, bottles for mineral water and juices, clothing, toys, household items and building materials. It has revolutionized the health care industry with the development of medical tools and devices including disposable items like surgical gloves, syringes, insulin pens, blood bags, catheters etc. to prevent spreading of infectious diseases. Especially during COVID-19 pandemic, the use of products like PPE kit, face masks has been increased significantly. Despite these excellent properties, plastic has become a major cause of pollution due to its non-biodegradability and toxic effects. Globally, more than 350 million tonnes (Mt) of plastic waste is generated annually, about $79 \%$ of which goes into landfill, only $9 \%$ is recycled and rest $12 \%$ is incerinated. Incineration of plastic waste releases toxic gases like polychlorinated biphenyls (BCPs), furans and dioxins into the atmosphere that poses a serious threat to environment affecting vegetation and marine ecosystem, in addition to human health. This review briefly covers various kinds of plastics and their applications in various sectors. The next section describes their potential hazards on the ecosystem and on human health. It also deliberates various methods for plastic waste reduction including recycling that enables a circular approach towards sustainable plastic waste management. The regulations and their implementation to reduce plastic waste are also discussed with special reference to India including extended producer responsibility for the plastic producers.
\end{abstract}

Key words: Plastic waste management, Health hazards, Plastic pollution, Recycling, Circular economy

\section{Introduction}

Most of the plastic, being a light-weight, hygienic and mouldable into different shapes, has wide range of applications such as in packaging, shopping/garbage bags, bottles, clothing, toys, household items, industrial products and building materials. It has replaced traditional materials like wood, leather, metal, glass, and ceramics etc. owing to its excellent strength to weight ratio, durability, low cost, low maintenance and corrosion free characteristics along with the fact that it is easy to manufacture. Plastic production has increased with 1.5 million metric tonne in 1950 to 367 in 2020 and that is expected to double by 2040 (Chen et al., 2021)
Plastic has transformed our life. Despite these excellent properties, It has become a major cause of pollution just because of its nonbiodegradability and hazardous and toxic effects. Plastic pollution was first noticed around late 60 s and early 70 s by the scientists studying marine planktons (Kenyon and Kridler, 1969). Nearly $79 \%$ of all the plastic waste generated goes into landfill, only $9 \%$ is recycled and rest $12 \%$ is incinerated (Geyer et al., 2017). Incineration of plastic waste is one of the major causes of air pollution duo to the release of toxic gases like furans dioxins, polychlorinated biphenyls (BCPs) and mercury into the atmosphere. It poses a serious threat to environment in terms of air, water 
and soil pollution affecting the vegetation and marine ecosystem, in addition human health.

It is, thus, the need of the hour to understand the extent of the problem and to act in the direction (i) to reduce plastic production and use, (ii) to increase its recycling and/or (iii) to search for alternative biodegradable plastic materials for sustainable plastic waste management to save our environment. The awareness about the harmful effects in the general public is also necessitated.

\section{Materials and Methods}

During the last decade, the damage caused by the plastic pollution has attracted the attention of scientists and environmentalists to read, write, research to resolve this global issue. The literature is flooded with review articles on plastic pollution in marine and land ecosystems and the atmosphere. Some of these recent reviews are consulted to have the latest information and types of research going on to combat plastic pollution which is one of the biggest global challenges of present times. The UNEP, government websites like CPCB and SPCB websites of India, are accessed to get the information about regulations for plastic pollution control in India and the extent to which these are implemented.

\section{Plastics and its various types}

Plastics are organic polymers of high molecular mass, mostly produced from petrochemicals. It is of two types thermoplastic and thermoset. The first synthetic plastic, Bakelite, was invented in 1907 and since then many different types of plastics materials have been produced, now classified into PET (Polyethylene terephthalate), LDPE (low density polyethylene), HDPE (high Density polyethylene), PVC (polyvinyl chloride), PUT (Polyurethanes), PP (polypropylene), PS (Polystyrene), and PP\&A fibres (polyphthalamide fibres) in thermoplastic category contributing to $80 \%$ of total plastic use. Bakelite, Epoxy, Melamine, Polyester, Polyurethane etc. constitute $20 \%$ of total plastic, come under thermoset category.

Plastic items have symbols, known as Resin Identification Codes (RICs), on them for identification of the type of polymer from which they are produced. There are 7 codes in all, identified by numbers from 1 to 7 within the recycling symbol which has been receiving criticism because it misleads consumers that all types of plastics are always recyclable.

\section{Environmental Degradation due to plastic}

Plastic poses threat to the environment specially the single use plastics (SUP). Packaging materials, which become waste within hours of use, accounts for around $36 \%$ of the total plastics production which is harmful for our environment (Geyer et al., 2017). Its burning in open releases black carbon and greenhouse gases into the atmosphere, causing air pollution and most of the SUP is dumped as landfills causing soil 
pollution and in turn entering into our food chain. A significant part of it reaches to oceans via rivers and drains, affecting marine life (Jambeck et. al., 2015). Nearly 8 million tonnes of plastics waste is discharged into ocean annually (Parker, 2015). Plastic takes hundreds of years to fully decompose, and is converted into micro- and nano plastics which are found floating over the ocean waters and disrupting oxygen supply to marine animals causing their deaths. These adversely affect the planktons and coral reefs (Chatterjee \& Sharma, 2019). Thousands of sea birds and marine mammals are killed annually due to ingestion of plastic or entangling in it. Plastics affect the growth of plants by reducing the fertility of soil, these can clog drains resulting in overflowing and responsible for floods in rainy season in countries like India, Bangladesh etc. These clogged water drains become the breeding grounds for mosquitoes and other insects causing vector borne diseases like malaria, dengue etc. The rainwater infiltration into the soil is hindered due to these polybags affecting the recharge of ground. Plastic bags swallowed by cattle may cause death.

\section{Human Health Hazards associated with Plastic}

The plastic disintegrates at extremely slow rate with the formation of micro- and nanoplastics due to weathering, UV radiation or during recycling process. These particles accumulate in the soil and water, from where they enter into our body via food intake. These can also enter into the human body directly by ingestion or inhalation and may cause damaging health effects including inflammation, genotoxicity, oxidative stress, cancer, cardiovascular diseases, diabetes, rheumatoid arthritis, auto-immune disorders, neuro-degenerative diseases, and stroke. The plastic additives which are used to modify the characteristic properties of plastic during its manufacturing, release into air and water also cause harmful effects. Dioxins found in plastics is carcinogenic (Alabi et al., 2019), can disturb thyroid functioning (Leijs et al., 2012) and respiratory systems (Leijs et al., 2018). Phthalates which gives flexibility and softness to plastic, generally found in medical devices, flooring materials, computers, pharmaceuticals and cosmetics etc., disrupt endocrine system (Campanale et al., 2020) causing several health problems including fertility issues, affecting babies along with normal allergic reactions like nausea, headaches and asthma.

\section{Single Use plastics}

Single-use plastics (SUPs) or the disposable plastics can be items made from HDPE, LDPE, PET, PS, PP and EPS (expanded polystyrene) including grocery bags, food packaging, foam take-away containers, bottles, straws, containers, cups and cutlery and packaging for fragile items etc. Online shopping has considerably increased the use of SUPs. The healthcare is one of the major industry where the SUPs are very frequently 
used. Acrylonitrile butadiene styrene (ABS) and PP are used in life-saving treatment. The disposable syringes (banned in UK and EU) intravenous (IV) tubing, surgical gloves and gowns, blood bags, generated as waste from hospital laboratories, operating rooms, emergency room and cafeteria which contribute to around two million tons of medical waste produced annually, $85 \%$ of which is non-hazardous. The rest $15 \%$ may be infectious, toxic and/or hazardous (https://www.who.int/news-room/factsheets/detail/health-care-waste). COVID -19 pandemic has significantly aggravated the medical waste generation. These plastic waste can be recycled if these are not infected or used during operations.

\section{Plastic waste management}

Nearly 9 billion tonnes of plastic has been produced till now since 1950 when its industrial production began with 1.5 million tonnes per year (Canopoli et al., 2018). As more than $99 \%$ of plastic is produced from chemicals derived from oil and natural gas, it would account for one fifth of the total oil consumption by the year 2050, if the plastic production continues at the current rate. Due to the non-biodegradability of the plastic, most of it finds its place in landfills, ocean, seas, beaches, ocean beds and is also circulating in the marine ecosystem through ocean gyres and polluting the whole environment globally, especially single use plastics which accounts for $50 \%$ of the total plastic production. Although plastic pollution was notice nearly 50 years back, its severity was realised nearly
2 decades back. The plastic waste generated during 1990-2000 was more than that during 1950-1990. Bangladesh flood of 1998 caused by blockage of waterways due to plastic bags made it the first country to ban plastic bags in 2002 (Ahmed \& Gotoh, 2005). Now, around 350 metric tonnes of plastic waste is generated by different sectors annually. These include building and construction materials (4.3\%), consumer products $(12.1 \%)$, electrical \& electronics products $(4.2 \%)$, industrial machinery $(0.4 \%)$, packaging material $(46 \%)$, textiles (14.9\%), transportation (5.6\%) and others (12.5\%) (Ncube et al. 2021). The associated effects on the environment, marine ecosystem and human population has reached to such a level that demands global coordinated efforts for plastic waste management and search for alternative biodegradable solutions along with the steps to reduce its production and uses, to cope with it. During the last 5-6 years, the steps are taken in this direction.

As the packaging sector accounts for nearly half of the total plastic waste, with online shopping may be one of the major contributors, it demands proper and easy solutions/alternatives to reduce the waste generation in this sector. Proper management of plastic waste is the biggest challenge due to lack of awareness about the proper guidelines for the disposal and recycling. Governments are adopting circular economy policies to reduce the burden of plastic waste on the earth and stress on the environment. Plastic 
recycling is one such step and companies across the globe are taking initiatives for it to reduce greenhouse gas emissions and turning plastic waste a resource.

\section{Recycling Strategies}

\section{Manual separation}

Manual separation is generally done by waste pickers, whereas recycling centers use a conveyor-belt. This process is utilized mostly for clear PET bottles.

\section{Density separation}

In this approach the plastic can be separated by taking advantage of differences in the densities of its different types using gravity separation.

\section{Sensor based separation}

It is an automated approach utilizing, near infrared spectroscopy involving different types of sensors attached to a computer. After analyzing, the items are directed towards appropriate belts. This method, however, can give misleading results for strongly coloured plastics and composite materials like multilayered packaging. For these items hyperspectral imaging can be applied. Although sensor based separation is expensive to install, it has high recovery rate with highquality products (Chidepatil et al., 2020; Kumar et. al., 2017)

\section{Mechanical Recycling}

This is the simplest as well as the most economical recycling method in which plastic waste is re-melted to form new products, having lower carbon footprint relative to other processes (Schyns \& Shaver, 2021). Additives like flame retardants present in the plastic can cause its degradation. Polymers immiscible with one another, when melted, require phase separation method for reprocessing. Flame retardants are, thus, removed by chemical treatment, whereas deactivators can make the metallic additives inert.

\section{Closed-loop recycling}

Closed-loop (or primary) recycling refers to a process by which a product or material can be converted into a new product (or converted back to the virgin material) without any degradation in its properties as well as with no waste generation ideally (Ügdüler et. al.,2020). That in turn saves the natural resources in addition to minimal harm to the environment. The waste turns out to be resource and is cost effective too. r-PETs produced at less cost, saving natural resources.

Solvent-based recycling using switchablepolarity solvents can be used for the extraction of polymers from mixed waste stream eg. multilayer packaging having a film of aluminium. The principle is based on the conversion of a hydrophobic amine into ammonium bicarbonate in the presence of water and carbon dioxide. The resultant hydrophilic anti-solvent precipitates the PE. When the pressure of carbon dioxide is released, the original amine is reformed and ready for reuse (Sherwood, 2020). Contaminations like PVC in PET, PE and PP can be removed using solvent extraction method. 
Table 1. Plastic waste of different categories generated along with their associated health hazards

\begin{tabular}{|c|c|c|c|c|c|}
\hline $\begin{array}{l}S . \\
\text { No. }\end{array}$ & Category & Items & Properties & $\begin{array}{l}\text { *plastic } \\
\text { production }\end{array}$ & Health hazards \\
\hline 1. & $\begin{array}{l}\text { PETE } \\
\text { Recyclable }\end{array}$ & $\begin{array}{l}\text { Bottles of soft drinks, } \\
\text { mineral water, fruit juices } \\
\text { and cooking oil etc. }\end{array}$ & $\begin{array}{l}\text { Smooth, } \\
\text { transparent and } \\
\text { thin strong, tough, } \\
\text { barrier to gas \& } \\
\text { moisture. }\end{array}$ & $7 \%$ & $\begin{array}{l}\text { Contains antimony } \\
\text { trioxide that can cause } \\
\text { cancer in a living tissue } \\
\text { (Snedeker, 2014) }\end{array}$ \\
\hline 2. & $\begin{array}{l}\text { HDPE } \\
\text { Recyclable }\end{array}$ & $\begin{array}{l}\text { Containers of milk, liquid } \\
\text { detergent, bleaching } \\
\text { agents, shampoo \& } \\
\text { conditioner, recycling bin }\end{array}$ & $\begin{array}{l}\text { Stiff, strong, } \\
\text { tough, moisture } \\
\text { resistance, has gas } \\
\text { permeability }\end{array}$ & $15 \%$ & $\begin{array}{l}\text { Disruption in hormonal } \\
\text { system due to leaching } \\
\text { of estrogen like } \\
\text { additives }\end{array}$ \\
\hline 3. & $\begin{array}{l}\text { PVC } \\
\text { Rarely } \\
\text { recycled }\end{array}$ & $\begin{array}{l}\text { Sweets trays, fruits } \\
\text { packing, wrapping foils } \\
\text { for food, Pipe, flooring, } \\
\text { shower curtains, chairs, } \\
\text { non-food bottles and toys }\end{array}$ & $\begin{array}{l}\text { Regular PVC is } \\
\text { rigid \& Brittle, } \\
\text { strong, tough } \\
\text { Flexible PVC is } \\
\text { soft, easily } \\
\text { blended, most } \\
\text { toxic plastic }\end{array}$ & $16 \%$ & $\begin{array}{l}\text { Can cause cancer; } \\
\text { allergic symptoms in } \\
\text { children disrupt } \\
\text { hormonal system due to } \\
\text { toxic BPA, phthalates, } \\
\text { lead, dioxins, mercury } \\
\text { \& cadmium. }\end{array}$ \\
\hline 4. & $\begin{array}{l}\text { LDPE } \\
\text { Quite difficult } \\
\text { to be recycled }\end{array}$ & $\begin{array}{l}\text { Grocery \& garbage bags, } \\
\text { bread, frozen food bags, } \\
\text { cling wrap beverage } \\
\text { cups; squeezable bottles, } \\
\text { containers, lids, wire \& } \\
\text { cable covering }\end{array}$ & $\begin{array}{l}\text { Flexible and easy } \\
\text { processing, good } \\
\text { sealant, resistant } \\
\text { to moisture and } \\
\text { chemicals }\end{array}$ & $17 \%$ & Non-hazardous \\
\hline 5. & $\begin{array}{l}\text { PP } \\
\text { Low recycling } \\
\text { rate }(1 \%)\end{array}$ & $\begin{array}{l}\text { food containers, } \\
\text { dishware, auto parts, } \\
\text { industrial fibres, }\end{array}$ & $\begin{array}{l}\text { Heat resistant, } \\
\text { grease \& oil } \\
\text { resistant, moisture } \\
\text { resistant, semi } \\
\text { transparent }\end{array}$ & $23 \%$ & $\begin{array}{l}\text { although safer plastic } \\
\text { for food and drinks, can } \\
\text { cause asthma \& } \\
\text { hormone disruption }\end{array}$ \\
\hline 6. & $\begin{array}{l}\text { Low recycling } \\
\text { rate }\end{array}$ & $\begin{array}{l}\text { disposable cups and } \\
\text { bowls, cup lids food } \\
\text { containers, egg cartons, } \\
\text { packaging, bike helmet, } \\
\text { trays, utensils, toys, CDs, } \\
\text { video cassettes and and } \\
\text { insulation board etc. }\end{array}$ & $\begin{array}{l}\text { Amorphous, low } \\
\text { heat resistant, } \\
\text { rigid, colorless, } \\
\text { transparent, } \\
\text { brittle, has good } \\
\text { electrical } \\
\text { properties but } \\
\text { poor chemical \& } \\
\text { UV resistance, } \\
\text { easily processed }\end{array}$ & $7 \%$ & $\begin{array}{l}\text { Can affect brain \& } \\
\text { nervous system due to } \\
\text { toxic styrene. Can also } \\
\text { affect genes, lungs, } \\
\text { liver, and immune } \\
\text { systems. }\end{array}$ \\
\hline 7. & $\begin{array}{l}\text { Other plastics } \\
\text { (acrylonitrile } \\
\text { acrylic, nylon } \\
\text { butadiene } \\
\text { polycarbonate, } \\
\text { styrene, poly } \\
\text { lactic acid } \\
\text { fiberglass) }\end{array}$ & $\begin{array}{l}\text { Baby bottles, sippy cups, } \\
\text { water bottles, water } \\
\text { gallon, metal food can } \\
\text { liner, ketchup container, } \\
\text { and dental sealants and } \\
\text { many more. }\end{array}$ & $\begin{array}{l}\text { Properties } \\
\text { dependent on } \\
\text { polymers or } \\
\text { combination of } \\
\text { polymers }\end{array}$ & $15 \%$ & $\begin{array}{l}\text { can alter immune } \\
\text { function, impair brain \& } \\
\text { neuro-logical functions, } \\
\text { damage cardio-vascular } \\
\text { system, cause Type II } \\
\text { diabetes, obesity, breast } \\
\& \text { prostate cancers, } \\
\text { metabolic disorders \& } \\
\text { infertility }\end{array}$ \\
\hline
\end{tabular}

Recyclable

*US Department of Energy. (July 11, 2019). Distribution of plastic production worldwide in 2018, by type

[Graph]. In Statista. Retrieved September 06, 2021,

from https://www.statista.com/statistics/968808/distribution-of-global-plastic-production-by-typel 


\section{Tertiary Recycling}

In the tertiary or feedstock /chemical recycling the polymers are reduced to their monomers, which are re-polymerized into fresh plastics through various processes such as methanolysis, hydrolysis, pyrolysis, hydrogenation, pyrolysis etc. Theoretically, this recycling can be done infinite number of times; as the impurities, dyes, additives and chemical defects are completely removed with each cycle (Thiounn \& Smith, 2020). However, technologies are yet to start on industrial scale. Glycolysis of PET into diols and dimethyl terephthalate is used to make virgin PET.

\section{Quaternary Recycling}

It is the process of energy recovery from the plastics which reduces the volume of the plastic waste involving incineration (Kumar, 2021). But it is not environmentally sound due to release of toxic gases into the atmosphere. However, the energy requirements for the primary and secondary recycling can be fulfilled by the tertiary and quaternary recycling, hence making these also a part of circular economy. This method does not require any type of sorting of waste and applied for any kind of plastic including those which have completed all possible rounds primary or secondary recycling and is at the end of life stage. Tire derived fuel come under this category.
Catalytic conversion of Plastic to Fuel by Pyrolysis

Various catalysts are used to improve the efficiency of pyrolysis of plastic waste as well as reduce the process temperature and time (Sarker et al., 2011a). A number of catalysts are used including $\mathrm{Ca}(\mathrm{OH})_{2}$ for conversion of PETE (Sarker et al., 2011a), HZSM-5 for HDPE conversion (Sarker et al., 2011b) into hydrocarbon fuels. Other catalysts used are ZSM-5, zeolite, Y-zeolite, FCC, and MCM-41 for different types of plastic waste either single or mixed in different ratios to get the optimum fuel production (Ratnasari et al., 2017). Metal nano-particles $(\mathrm{Pt})$ is found to have very effective catalytic property, when deposited on tungstate-zirconia and used with zeolite, for the liquid fuel yield at much lower temperature, pressure and also time (Liu et al., 2021).

\section{United Nation's Initiatives for Plastic Pollution}

Since plastic pollution is affecting everyone on the planet, the international agency like United Nations (UN) has to take initiative in tackling the issue. To spread awareness, $3^{\text {rd }}$ July is designated as 'International Plastic free day' by UN in 2008. Every country has different sets of regulations to fight plastic pollution. Banning plastic bags is the first step. However, globally, there are seven different definitions for a plastic bag, making it difficult for the global companies like Nestle, Coca cola and many more to comply. It was, thus, felt the need of 
coordinated efforts from all the stake holders and that, there should be a fixed set of rules for every country. Realizing the severity of effect of plastic pollution on the marine ecosystem, a joint resolution was passed by 194 countries on marine litter and microplastics at the United Nations Environmental Assembly (UNEA) in a meeting in December 2017 to reduce plastics reaching the ocean. As a result, "break free from plastic movement" began. The United Nations Economic and Social Commission for Asia and the Pacific (ESCAP) had launched another project to reduce the environmental impact of cities in South East Asia along with Government of Japan in May 2020, in the light of the reports that the $90 \%$ of ocean plastic pollution is due to ten rivers across the globe, eight of which are in Asia (Van Calcar \& Van Emmerik, 2019).

Several countries have introduced regulations based on plastic production, use and waste disposal and recycling related to it, to reduce use and improve waste management. More than 60 countries have introduced bans and taxes/fines on plastic packaging and single-use waste along with extended producer responsibility (EPR).

Global Awareness and its impact on fight against plastic pollution

Public pressure can enforce for policy decision-making and its proper implementation. It was found that small initiatives by public/students made a big difference. Some such examples are given below- Afroz Shah, an Indian lawyer and environmentalist from Mumbai, along with his then 84-year-old neighbour started beach cleaning themselves, inspiring thousands more to join for "dates with the ocean" to remove 13,000 tons of waste, mostly plastics in two years from 2015-

2017.(https://www.unep.org/news-andstories/press-release/afroz-shah-and-unenvironment-celebrate-100-week-anniversaryworlds)

Akshar Foundation in Assam (India) started a unique programme 'plastic-for-schooling' in which parents pay plastic as school fee which is converted into bricks. The foundation is now working under The United Nations Environment Programme (UNEP)'s “Tide Turners Plastic Challenge' program (https://www.unep.org/news-andstories/story/can-plastic-bottle-be-ticketeducation-india-yes)

The campaign taken over by two teenage sisters in Bali island for four years, with a petition having 100,000 signatures, got plastic bags banned in the island (https://edition.cnn.com/2017/08/16/asia/melat i-isabel-wijsen-bali/index.html). Similarly, in New Zealand, a petition launched by a group of high school students forced the government to impose a NZD 0.10 fine/tax on all plastic bags in supermarkets. Companies breaking New Zealand's ban can face heavy punishments along with fines of up to NZ\$100,000. (https://phys.org/news/2019-07zealand-single-use-plastic-bags.html) 
These incidents not only compel the governments to act on fighting pollution but could amplify the spreading awareness about plastic pollution and to act individually, locally to get effective outcome.

\section{India's Fight against Plastic Pollution}

India had generated nearly $3.36 \mathrm{Mt}$ of plastic waste during 2018-19. Although it is much less in terms of plastic waste produced per person per annum $(11 \mathrm{Kg})$ as compared to USA
$(109 \mathrm{Kg})$, but is enough to affect the environment and the people's health. As most of it is single use plastic, India has decided to completely phase out it by the year 2022 . Sikkim implemented ban on plastic bags way back in 1998 and so far, around 18 states and UTs have imposed bans. But merely announcing a ban or framing regulations cannot solve the problem, those should be strictly enforced and monitored as well. This requires behavioural change in the public.

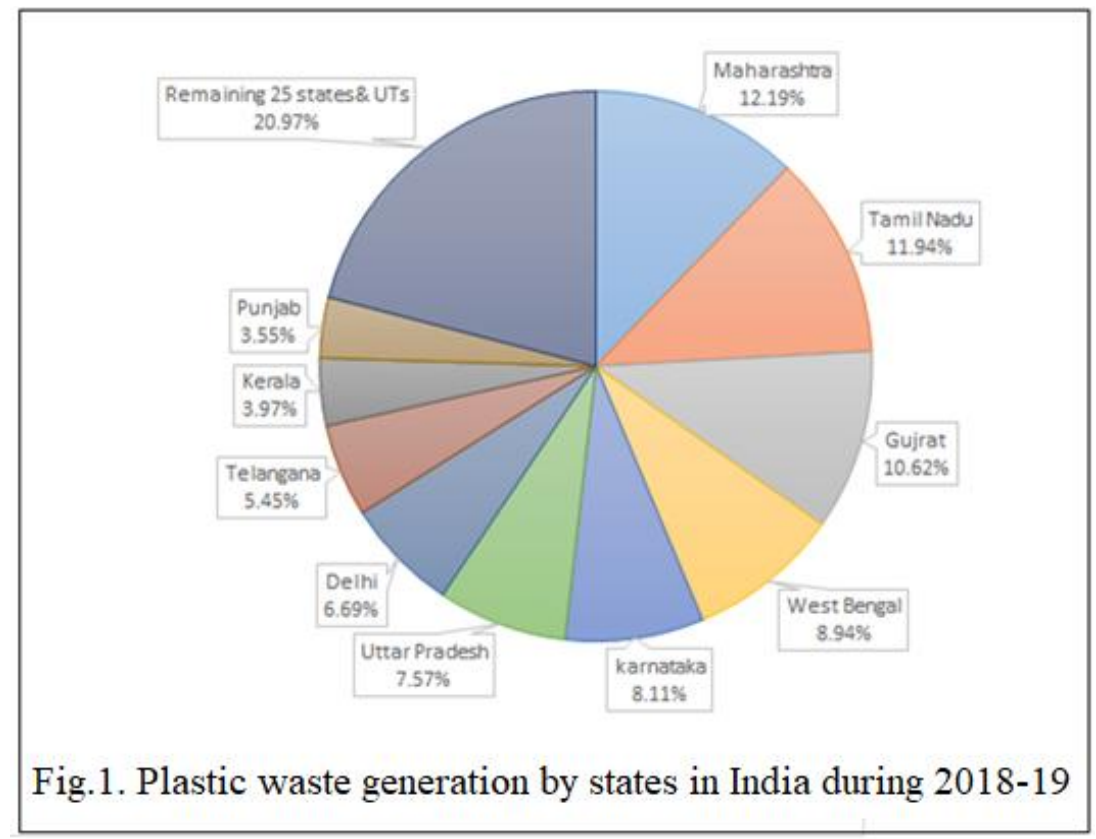

Fig. 1 shows the plastic waste generation by different states of India (http__cdn.cseindia.org_attachments_0.34437100_1599806161_managing-plastic-waste-inindia.pdf). According to it, only 10 states- Maharashtra, Tamil Nadu, Gujarat, West Bengal, Karnataka, Uttar Pradesh and Delhi, Telangana, Kerala and Punjab contribute to more than $80 \%$ of the plastic waste generated in India.

India had its first Plastic Waste (Management \& Handling) Rules, in 2011.Second rule Plastic Waste Management (PWM) Rules, 2016 included extended producer responsibility (EPR)in March, 2016, which was subsequently amended as 'Plastic Waste Management (Amendment) Rules, 2018 which lay down the phasing out of non-recyclable, or non-energy recoverable/ no use multi-layered Plastic (MLP). It also prescribed registration 
for plastic producers, recyclers and importers etc. and 93 brand owners/manufacturers have been registered till mid of 2020 .

Plastic Waste Management utilizes top down approach with the application of Reduce, Reuse recycle and recovery are the 4 R's principle. Reduce refers to minimize/stop using plastic bag, water bottle use cloth or jute bags, donate to others (reuse), company should arrange for $100 \%$ collection of waste generated by them to recycle, if not recyclable, plastic waste should be used for energy recovery (fuel generation) so that minimum goes to landfill.

In India, plastic waste is used for road construction. One lakh kilometres of roads in at least 11 states using discarded plastic has already been built since 2015 when it became mandatory for all road developers to use plastic waste for road construction. The construction cost is less and also no maintenance required for $10-15$ years. The technology was developed by Padma Sri Rajagopalan Vasudevan, a chemistry professor from Madurai's Thiagarajar College of Engineering in 2001. He is known as Plastic man of India (https://www.theguardian.com/world/2018/jul/ 09/the-man-who-paves-indias-roads-with-oldplastic). Plastic waste is converted to alternate fuel using environment friendly by coprocessing in Cement kiln utilizing the calorific value of all types of plastics fall in the same range as coal, coke or fuel oil (Suthar et al. 2020).

\section{Biodegradable and Bio plastics}

Biodegradable plastics is the best option for plastics, that degrade/break down when exposed to sunlight /UV radiation, water or dampness, bacteria, enzymes or wind abrasion. Degradation can be aerobic when plastic be exposed at the surface or anaerobic in landfill or composting systems (Folino et al., 2020). Bioplastics are made substantially from renewable plant materials such as cellulose and starch. Researchers have genetically engineered bacteria to produce completely biodegradable plastics (Kaparapu, 2018). Bioplastics are made from renewable materials such as poly lactic acid from corn or cellulosic from cotton fibers. Now, it has also been discovered that certain bacteria possess enzymes that are capable of degrading and digesting plastics (Maity et al., 2021; Jahnke,, 2020). Researches are on to have more environment friendly solutions for the degradation of plastics.

\section{Conclusion}

Despite having excellent properties like strength, durability, low cost, low maintenance and corrosion free, plastic has become a major cause of pollution due to its nonbiodegradability and toxic effects. Various methods are employed to reduce the plastic waste which is mostly in the form of landfills (Vince \& Hardesty, 2018). These enable a circular approach towards the sustainable plastic waste management. The regulations and their implementation to reduce plastic 
waste are also imposed including fine/tax including extended producer responsibility for the plastic producers. The overall recycling rate of plastic in India is $60 \%$ for all types of plastics, which includes the recycling rate of $90 \%$ for

PETE

(https://www.hindustantimes.com/mumbainews/india-recycles-90-of-its-pet-wasteoutperforms-japan-europe-and-us-study/storyyqphS1w2GdlwMYPgPtyb2L.html). Efforts should be increase the overall recycling rate to $90 \%$. The global problem of plastic pollution should be tackled by coordinated efforts of all the countries involving policy makers, governments, each and every stakeholder. Plastic pollution causing threat to marine life should be handled as early as possible. The efforts needed 4 R's policy-reduce, reuse, recycle and recovery (energy) to have minimum waste for landfills. Industry should also promote $\mathrm{R} \& \mathrm{D}$ to work on packaging alternatives that is generating most of plastic waste. The biodegradability of plastic is the current area of research to have feasible low cost environment friendly solution. It should be treated as resource for energy to tackle possible future energy crises due to depletion of natural resources. Value for the waste can also encourage the people to take their plastic waste to recycling/waste collection centres. IoT- based collection of plastic waste should be employed in smart cities (Aleyadeh \& Taha, 2018).

\section{References}

Ahmed, S. U., \& Gotoh, K. (2005). Impact of banning polythene bags on floods of
Dhaka City by applying CVM and remote sensing. In Proceedings. 2005 IEEE International Geoscience and Remote Sensing Symposium, 2005. IGARSS'05. (Vol. 2, pp. 1471-1474). IEEE.

Alabi, O. A., Ologbonjaye, K. I., Awosolu, O., \& Alalade, O. E. (2019). Public and environmental health effects of plastic wastes disposal: a review. J Toxicol Risk Assess, 5(021), 1-13.

Aleyadeh, S., \& Taha, A. E. M. (2018). An IoT-Based architecture for waste management. In 2018 IEEE International Conference on Communications Workshops (ICC Workshops) (pp. 1-4). IEEE.

Campanale, C., Massarelli, C., Savino, I., Locaputo, V., \& Uricchio, V. F. (2020). A detailed review study on potential effects of microplastics and additives of concern on human health. International journal of environmental research and public health, 17(4), 1212.

Canopoli, L., Fidalgo, B., Coulon, F., \& Wagland, S. T. (2018). Physico-chemical properties of excavated plastic from landfill mining and current recycling routes. Waste Management, 76, 55-67.

Chatterjee, S., \& Sharma, S. (2019). Microplastics in our oceans and marine health. Field Actions Science Reports. The Journal of Field Actions, (Special Issue 19), 54-61.Chen, Y., Awasthi, A. K., Wei, F., Tan, Q., \& Li, J. (2021). Single-use plastics: Production, usage, disposal, and adverse impacts. Science of the total environment, 752, 141772. https://doi.org/10.1016/j.scitotenv.2020.1 $\underline{41772}$

Chidepatil, A., Bindra, P., Kulkarni, D., Qazi, M., Kshirsagar, M., \& Sankaran, K. (2020). From trash to cash: how blockchain and multi-sensor-driven artificial intelligence can transform circular economy of plastic waste?. Administrative Sciences, 10(2), 23.

Folino, A., Karageorgiou, A., Calabrò, P. S., \& Komilis, D. (2020). Biodegradation of wasted bioplastics in natural and industrial environments: A review. Sustainability, 12(15), 6030. 
Geyer, R., Jambeck, J. R., \& Law, K. L. (2017). Producción, uso y destino de todos los plásticos jamás fabricados. Science Advances, 3(7), 12071221.

Jahnke, A. (2020). A discussion of single-use plastics in medical settings. Reinforced Plastics, 64(4), 190-192.

Jambeck, J. R., Geyer, R., Wilcox, C., Siegler, T. R., Perryman, M., Andrady, A., ... \& Law, K. L. (2015). Plastic waste inputs from land into the ocean. Science, 347(6223), 768-771.

Kaparapu, J. (2018). Polyhydroxyalkanoate (PHA) Production by Genetically Engineered Microalgae: A Review. $J$. New Biol. Rep, 7, 68-73.

Kenyon, K. W., \& Kridler, E. (1969). Laysan Albatrosses swallow indigestible matter. Auk, 86, 339-343.

Kumar, B. S., Varalakshmi, N., Lokeshwari, S. S., Rohit, K., \& Sahana, D. N. (2017). Eco-friendly IOT based waste segregation and management. International Conference on Electrical, Electronics, Communication, Computer, and Optimization Techniques (ICEECCOT) (pp. 297-299).

Kumar, R. (2021). Tertiary and quaternary recycling of thermoplastics by additive manufacturing approach for thermal sustainability. Materials today: proceedings, 37, 2382-2386.

Leijs, M. M., ten Tusscher, G. W., Olie, K., van Teunenbroek, T., van Aalderen, W. M., de Voogt, P., Vulsma, T., Bartonova, A, Krauss, M.K., Mosoiu, C., RiojasRodriguez, H., Calamandrei, G. \& Koppe, J. G. (2012). Thyroid hormone metabolism and environmental chemical exposure. Environmental Health,11(1), 1-7.

Leijs, M. M., Koppe, J. G., Olie, K., De Voogt, P., Van Aalderen, W., \& Ten Tusscher, G. W. (2018). Exposure to Environmental Contaminants and Lung Function in Adolescents-Is There a Link?. International journal of environmental research and public health, 15(7), 1352.

Liu, S., Kots, P. A., Vance, B. C., Danielson, A., \& Vlachos, D. G. (2021). Plastic waste to fuels by hydrocracking at mild conditions. Science Advances, 7(17), eabf8283.

Maity, W., Maity, S., Bera, S., \& Roy, A. (2021). Emerging Roles of PETase and MHETase in the Biodegradation of Plastic Wastes. Applied Biochemistry and Biotechnology, 1-18.Ncube, L. K., Ude, A. U., Ogunmuyiwa, E. N., Zulkifli, R., \& Beas, I. N. (2021). An Overview of Plastic Waste Generation and Management in Food Packaging Industries. Recycling, 6(1), 12.

Parker, L. (2015). Eight million tons of plastic dumped in ocean every year. National Geographic, February, 13.

Ratnasari, D. K., Nahil, M. A., \& Williams, P. T. (2017). Catalytic pyrolysis of waste plastics using staged catalysis for production of gasoline range hydrocarbon oils. Journal of analytical and applied pyrolysis, 124, 631-637.

Sarker, M., Kabir, A., Rashid, M.M. and Molla $\mathrm{M}$ and Din Mohammad A.S.M. (2011) Waste Polyethylene Terephthalate (PETE-1) Conversion into Liquid Fuel, 1 doi:10.4303/jfrea/R101202

Sarker, M., Rashid, M.M. and Molla M (2011) Abundant High-Density Polyethylene (HDPE-2) Turns into Fuel by Using of HZSM-5 Catalyst, 1, doi:10.4303/jfrea/R110201

Schyns, Z. O., \& Shaver, M. P. (2021). Mechanical recycling of packaging plastics: A review. Macromolecular rapid communications, 42(3), 2000415.

Sherwood, J. (2020). Closed-loop recycling of polymers using solvents. Johnson Matthey Technology Review, 4-15.

Suthar M., Lata N. \& Nagar B, (2020), Plastic Waste as an Alternate Fuel, International J. Engineering Research \& Technology (IJERT) Volume 9(7) doi : http://dx.doi.org/10.17577/IJERTV9IS0 70572

Snedeker, S. M. (2014). Antimony in food contact materials and household plastics: uses, exposure, and health risk considerations. In Toxicants in Food Packaging and Household Plastics (pp. 205-230). Springer, London.

Thiounn, T., \& Smith, R. C. (2020). Advances and approaches for chemical recycling of 
plastic waste. Journal of Polymer Science, 58(10), 1347-1364.

Ügdüler, S., Van Geem, K. M., Denolf, R., Roosen, M., Mys, N., Ragaert, K., \& De Meester, S. (2020). Towards closed-loop recycling of multilayer and coloured PET plastic waste by alkaline hydrolysis. Green Chemistry, 22(16), 5376-5394.
Van Calcar, C. J., \& Van Emmerik, T. H. M. (2019). Abundance of plastic debris across European and Asian rivers. Environmental Research Letters, 14(12), 124051.

Vince, J., \& Hardesty, B. D. (2018). Governance solutions to the tragedy of the commons that marine plastics have become. Frontiers in Marine Science, 5, 214. 